\title{
Routine diagnosis of human rotaviruses in stools
}

\author{
G. ZISSIS, J. P. LAMBERT, AND D. DE KEGEL \\ From the Department of Microbiology, St Pierre Hospital, Free University of Brussels, and the \\ Department of Electron Microscopy, Institut Pasteur du Brabant, Brussels, Belgium
}

SUMMARY Electron microscopy, immune electron microscopy, and complement fixation as methods of detecting rotavirus in the stools of young children with gastroenteritis were compared in a blind study during the winter of 1975-6. Complement fixation was the simplest to perform, was as sensitive as the other two, and allowed a quantitative measurement of viral excretion. Absorption of faecal extracts with fetal calf serum usually removed the anticomplementary activity of faecal extracts.

Bishop et al. (1973) and Flewett et al. (1973) found reovirus-like particles (RVL) in both the duodenal mucosa and stools of children with acute gastroenteritis. Since then many others (Cruickshank et al., 1974; Holmes et al., 1974; Kapikian et al., 1974; Middleton et al., 1974; Ørstavik et al., 1974; Tan et al., 1974; White et al., 1974; Conklin et al., 1975; Konno et al., 1975; Schoub et al., 1975; Zissis and De Kegel, 1975) have associated these particles with infantile gastroenteritis and variously named them rotavirus, duovirus, reovirus-like (RVL) particles, and infantile gastroenteritis virus (IGV).

Whatever the name, there is no longer any doubt that this is a cosmopolitan virus causing localised epidemics in winter. It is now considered to be one of the major causes of non-bacterial gastroenteritis in children under 5 years, but it occasionally infects older children (Hara et al., 1976) and even adults (Gomez-Baretto et al., 1975; Zissis et al., 1976).

Unfortunately no one has yet obtained a cytopathic effect on cell culture with human rotavirus. Therefore the diagnosis of diarrhoea caused by it relies generally on electron microscopy (EM, negative contrast). This is certainly not a routine procedure and could be used only in research laboratories. Nevertheless, in the absence of susceptible tissue cultures to support the virus, several workers (Spence et al., 1975; Banatvala et al., 1975) have tried to find an alternative to the electron microscope to detect these particles. In this paper we present evidence to support the use of a sensitive 'microtitre' complement fixation test (CF) as a diagnostic tool for rotavirus.

Following the example of Spence et al. (1975), we compared two techniques-EM and CF. In a

Received for publication 18 July 1977 second study we compared EM, IEM, and CF. In both studies the specimens were coded so that the persons carrying out the tests could not know what result might be expected.

\section{Material and methods}

\section{FIRST COMPARATIVE STUDY}

From December 1975 to March 1976, 196 stool specimens were collected from children with acute diarrhoea who came to the paediatric clinic at St Pierre Hospital, Brussels. Faecal suspensions were prepared as described below and examined by EM and CF.

\section{SECOND COMPARATIVE STUDY}

During the month of April 1976, 20 further stool specimens were collected and examined by EM, IEM, and CF.

\section{PREPARATION OF FAECAL SUSPENSIONS}

Stool specimens were suspended about $30 \%(v / v)$ in PBS with antibiotics and centrifuged at $5000 \mathrm{rev} /$ min for $10 \mathrm{~min}$ in conical centrifuge tubes. The supernatant was again centrifuged at $5000 \mathrm{rev} / \mathrm{min}$ for $10 \mathrm{~min}$. This clarified supernatant of the second centrifugation was used as the antigen in all tests.

\section{ELECTRON MICROSCOPY}

Four millilitres of the clarified supernatant were centrifuged at $50000 \mathrm{rev} / \mathrm{min}(249000 \mathrm{~g})$ for one hour in a Beckman centrifuge (Spinco swinging rotor SW $65 \mathrm{~L} \mathrm{Ti}$ ). The pellet was resuspended in $0.5 \mathrm{ml}$ distilled water. Electron microscope grids, covered by a formvar membrane, were placed on a drop of the suspension for $15 \mathrm{~min}$. After the virus had adsorbed to the membranes and they had dried 175 
they were rinsed four times in a drop of saline, being blotted after each dip, and were then negatively stained with $2 \%(w / v)$ uranyl acetate for 15 seconds. After drying the grids were examined by a 201 Philips electron microscope.

\section{IMMUNE ELECTRON MICROSCOPY}

Four volumes of clarified supernatant were mixed with one volume of convalescent human serum diluted 1:8. This convalescent serum gave a CF titre of $1: 128$ when titrated against an extract of faeces known to contain human rotavirus. The mixture was left at room temperature for two hours and at $4^{\circ} \mathrm{C}$ overnight. It was then centrifuged at $50000 \mathrm{rev} / \mathrm{min}(249000 \mathrm{~g})$ for one hour. The pellet was prepared for EM as described above.

\section{SENSITIVE COMPLEMENT FIXATION}

MICROTECHNIQUE

This technique has been described elsewhere (Zissis and Clinet, 1974). Briefly, it is a method using $0.25 \%$ sheep red blood cells, one optimal sensitising dose of haemolytic serum, and two HD $\mathrm{H}_{100}$ (haemolytic dose) of complement. In the test itself $25 \mu 1$ of clarified supernatant were mixed with $25 \mu$ l of human rotavirus antiserum and $25 \mu \mathrm{l}$ of complement $\left(2 \mathrm{HD}_{100}\right)$. After standing overnight at $4^{\circ} \mathrm{C} 50 \mu \mathrm{l}$ of sensitised red blood cells were added and the 'microtitre' plates ${ }^{1}$ were incubated at $37^{\circ} \mathrm{C}$ for one hour. Then they were centrifuged for 30 seconds at $3000 \mathrm{rev} / \mathrm{min}$ before the results were read. This gave clear buttons of red cells.

Absorption of clarified supernatant with complement Sometimes the clarified supernatant was anticomplementary. In order to eliminate this problem the supernatant was absorbed with an equal volume of complement diluted to $4 \mathrm{HD}_{100}$ for two hours at $4^{\circ} \mathrm{C}$. The complement was then inactivated by heating in a water bath at $56^{\circ} \mathrm{C}$ for $30 \mathrm{~min}$. The mixture was then ready to be used as antigen in the CF test.

Absorption of clarified supernatant with fetal calf serum (FCS)

With the same goal in mind as above $25 \mu$ l of clarified supernatant was mixed with $25 \mu$ l of fetal calf serum previously found to be free of calf antirotavirus antibody by testing with calf scours virus. Then serial dilutions were made starting with $25 \mu 1$ of the mixture in $25 \mu 1$ of buffer. The anticomplementarity (AC) of these different dilutions was tested.

${ }^{1}$ Cooke Microtiter $\mathbf{R}$ plates with V-bottom wells.

\section{Results}

FIRST COMPARATIVE STUDY

In this study 149 clarified faecal suspensions wereo found negative by both techniques, 44 were foundo positive by EM, and 47 postive by CF. Later the three specimens that were initially detected only by CF were confirmed as positive by EM.

SECOND COMPARATIVE STUDY

In the light of the results of the first study we believed that CF could advantageously replace EM.. Nevertheless, we wanted to see if it was possible to increase the sensitivity of detection of rota- $\dot{\omega}$ viruses by using IEM. Contrary to expectation. IEM was not more sensitive than the other two (Table 1). Indeed, five of the 20 stools examined $\bar{G}$ yielded rotavirus, as was also demonstrated by theo other methods. With IEM the particles aggregatedbut this did not render the diagnosis any easier nor did it increase the number of specimens foundo positive.

Table 1 Comparative trial of detection of human $R V L$ particles

\begin{tabular}{|c|c|c|c|c|}
\hline \multirow[b]{2}{*}{ Stool } & \multicolumn{3}{|c|}{ Rotavirus detected by: } & \\
\hline & $E M$ & IEM & $C F^{*}$ & ב \\
\hline 1 & + & + & $+(128)$ & 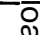 \\
\hline 4 & + & + & $+(32)$ & 음 \\
\hline 7 & + & + & $+(256)$ & D \\
\hline 9 & + & + & $+\quad(2)$ & $=$ \\
\hline 10 & + & + & $+(16)$ & $\overline{\overline{0}}$ \\
\hline $\begin{array}{l}6,8 \\
11-20\end{array}$ & - & - & - & $\Rightarrow$ \\
\hline
\end{tabular}

*Antigen titre expressed as dilution reciprocals in parentheses. $\mathbf{E M}=$ electron microscopy. IEM = immune electron microscopy. $\mathrm{CF}=$ complement fixation.

ANTICOMPLEMENTARITY (AC) OF CLARIFIED SUPERNATANTS

As shown in Table 2, some supernatants were $D$ anticomplementary. To remedy this two absorption을 techniques were compared using six faecal extracts $N$ in which the anticomplementarity titre varied from $\sigma$ 4 to 16 and which were negative by EM for rotavirus. $N$ The absorption with guinea-pig complement had $\omega$ no influence on AC. On the other hand, absorption with fetal calf serum eliminated $A C$ in five out of 0 six specimens without affecting the titre of the posi- $\frac{C}{\mathbb{D}}$ tive control (No. 39). The idea of a beneficial effect $\stackrel{\infty}{+}$ of fetal calf serum (FCS) on $A C$ came from the $T$ empirical observation that faecal suspensions pre- $\frac{O}{\Phi}$ pared for inoculation on cell cultures (in growth $\varrho$ medium with $10 \%$ FCS) were consistently less $\stackrel{\square}{\square}$ 
Table 2 Comparison of two different techniques for treating clarified supernatants to eliminate anticomplementarity

\begin{tabular}{|c|c|c|c|c|c|c|c|}
\hline \multirow[t]{2}{*}{ Clarified supernatant No: } & \multirow[t]{2}{*}{$E M$} & \multicolumn{2}{|c|}{ Non-absorbed supernatant } & \multicolumn{2}{|c|}{ Supernatant absorbed with $C^{\prime}$} & \multicolumn{2}{|c|}{ Supernatant absorbed with FCS } \\
\hline & & $A C T$ & $C F T$ & $A C T$ & CFT & $A C T$ & $C F T$ \\
\hline 35 & - & 16 & 16 & 16 & 16 & 0 & 0 \\
\hline 57 & - & 8 & 8 & 8 & 8 & 0 & 0 \\
\hline 98 & - & 8 & 8 & 8 & 8 & 8 & 8 \\
\hline 115 & - & 8 & 8 & 8 & 8 & $\mathbf{0}$ & 0 \\
\hline 143 & - & 8 & 8 & 8 & 8 & 0 & 0 \\
\hline 178 & - & 4 & 4 & 4 & 4 & 0 & 0 \\
\hline 39 & + & 0 & 16 & 0 & 16 & 0 & 16 \\
\hline
\end{tabular}

$\mathrm{ACT}=$ anticomplementarity titre. $\mathrm{CFT}=$ complement fixation titre. $\mathbf{C}^{\prime}=$ complement. $\mathrm{FCS}=$ fetal calf serum.

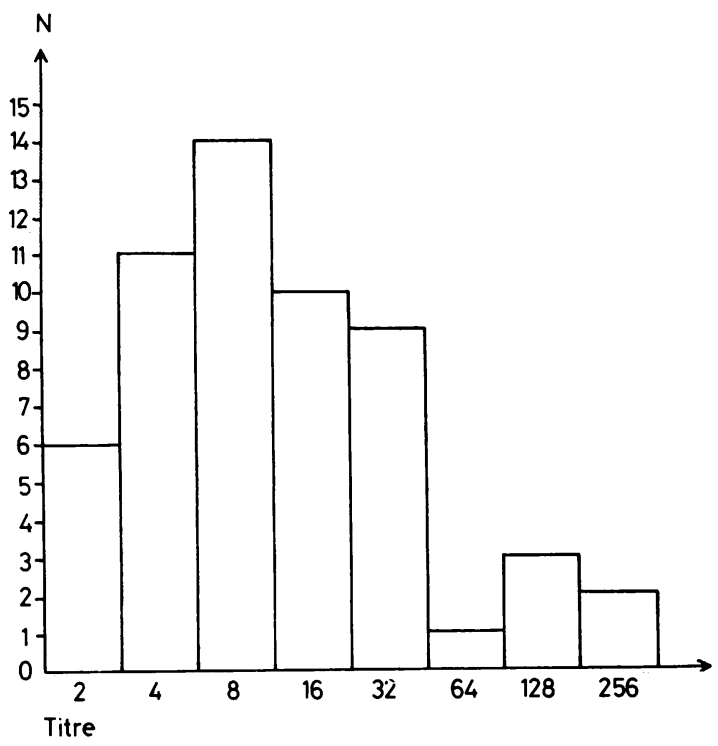

Figure Amount of rotavirus excreted in stools. $N=$ number of rotavirus-positive stools. Titre $=$ rota CF antigen titre expressed as dilution reciprocals.

anticomplementary than faecal suspensions prepared in PBS for CF.

\section{MEASUREMENT OF VIRAL EXCRETION}

In addition to detecting rotavirus $\mathrm{CF}$ also allows viral excretion to be measured. We have shown in the Figure the titre of rotavirus antigen by $\mathrm{CF}$ from 56 stools that were confirmed positive by EM. The titre lies between 4 and 32 in $80 \%$ of cases. We have seen several cases of acute gastroenteritis (unpublished data) in which a titre of $\geqslant 64$ was readily obtained at the climax of viral excretion and which diminished ,rapidly in succeeding days.

Serum from three sources may be used to detect rotavirus antigen. (1) rabbit antiserum (against Nebraska calf diarrhoea virus (NCDV); (2) calf convalescent serum; or (3) a human serum if the CF antibody titre is high enough. Human serum can easily be obtained by screening sera from children aged 1-3 years with the aid of calf antigen (NCDV) if human rota antigen is not available.

Sera with titres $\geqslant 128$ are not uncommon. By using these at dilutions of $1: 16$ or $1: 32$ non-specific reactions were avoided. We found that sera of human origin gave better results and that the rabbit antisera must be used with caution since the anticomplementary titre is close to the antibody titre. Calf convalescent serum was also suitable, but the antigen titres obtained were two to four times lower than with human serum.

\section{Discussion}

Of the three methods (EM, IEM, CF) of detecting rotavirus we prefer $C F$ because (1) its specificity is high; (2) the preparation of the antigen is much simpler, since only a clarified supernatant absorbed with fetal calf serum is required; (3) its objectivity is greater and the diagnosis does not depend on skill in finding particles, as with the EM. Furthermore, CF has a distinct advantage in that it can measure the amount of virus excreted in the stools.

Two of the minor limitations of CF are that the detection of the antigen necessitates using a human serum, or an antiserum against NCDV, and sometimes the supernatant of the faecal suspension is anticomplementary; this can be eliminated with remarkable ease by adding an equal volume of fetal calf serum. Whatever the technical problems, we believe they are fewer than those encountered in the other methods. On the other hand, the advantages (reliability, speed of execution, and the ready availability of the materials) are undeniable and make CF a tool accessible to all diagnostic virology laboratories.

We thank Dr D. Dalton for advice and kind collaboration in preparing this paper. 


\section{References}

Banatvala, J. E., Totterdell, B., Chrystie, I. L., and Woode, G. N. (1975). In-vitro detection of human rotaviruses (Letter). Lancet, 2, 821.

Bishop, R. F., Davidson, G. P., Holmes, I. H., and Ruck, B. J. (1973). Virus particles in epithelial cells of duodenal mucosa from children with acute nonbacterial gastroenteritis. Lancet, 2, 1281-1283.

Conklin, R. H., Dupont, H. L., Goldschmidt, M. C., and Rodriguez, J. T. (1975). Occurrence of 'viral particles' in diarrhea: Houston, Texas and Guatemala (Letter). Nen England Journal of Medicine, 292, 644-645.

Cruickshank, J. G., Axton, J. H. M., and Webster, O. F. (1974). Viruses in gastroenteritis (Letter). Lancet, 1, 1353.

Flewett, T. H., Bryden, A. S., and Davies, H. (1973). Virus particles in gastroenteritis (Letter). Lancet, 2, 1497.

Gomez-Baretto, J., Palmer, E., Hatch, M., and Nahmias, A. J. (1975). Occurrence of 'viral particles' in diarrhea: Atlanta, Georgia (Letter). New England Journal of Medicine, 292, 1297.

Hara, M., Mukoyama, J., Tsuruhara, T., Saito, Y., and Tagaya, I. (1976). Duovirus in schoolchildren with gastroenteritis (Letter). Lancet, 1, 311.

Holmes, I. H., Mathan, M., Bhat, P., Albert, M. J., Swaminathan, S. P., Maiya, P. P., Pereira, S. M., and Baker, S. J. (1974). Orbiviruses and gastroenteritis (Letter). Lancet, 2, 658-659.

Kapikian, A. Z., Kim, H. W., Wyatt, R. G., Rodriguez, W. J., Ross, S., Cline, W. L., Parrott, R. H., and Chanock, R. M. (1974). Reoviruslike agent in stools: association with infantile diarrhea and development $\underline{\bar{\sigma}}$ of serologic tests. Science, 185, 1049-1053.

Konno, T., Suzuki, H., and Ishida, N. (1975). Revirus like agent in Japanese infants with gastroenteritiso (Letter). Lancet, 1, 918-919.

Middleton, P. J., Szymanski, M. T., Abbott, G. D., Bortolussi, R., and Hamilton, J. R. (1974). Orbivirus acute gastroenteritis of infancy. Lancet, 1, 1241-1244.

Ørstavik, I., Figenschau, J., and Ulstrup, J. C. (1974).ఱ్ 'Rotavirus' in stored specimens of faecal extracts(Letter). Lancet, 2, 1083.

Schoub, B. D., Koornhof, H. J., Lecatsas, G., Prozesky, O. W., Freiman, I., Hartman, E., and Kassel, H.ब (1975). Viruses in acute summer gastroenteritis in⿳亠口冋 black infants (Letter). Lancet, 1, 1093-1094.

Spence, L., Fauvel, M., Bouchard, S., Babiuk, L., and $\stackrel{\omega}{-}$ Saunders, J. R. (1975). Test for reovirus-like agent (Letter). Lancet, 2, 322.

Tan, G. S., Townley, R. R. W., Davidson, G. P., Bishop, G R. F., Holmes, I. H., and Ruck, B. J. (1974). Virus in음 faecal extracts from children with gastroenteritis(Letter). Lancet, 1, 1109.

White, G. B. B., Ashton, C. I., Roberts, C., and Parry, H. E. (1974). 'Rotavirus' in gastroenteritis (Letter) Lancet, 2, 726.

Zissis, G., and Clinet, G. (1974). Viral-antibody detectionby a more sensitive complement-fixation reaction (Letter). Lancet, 1, 754.

Zissis, G., and De Kegel, D. (1975). Presence of Reoviruslike particles in liquid stools. Acta Gastro-Enterologicas Belgica, 38, 242-245.

Zissis, G., Lambert, J. P., Fonteyne, J., and De Kegel, D유 (1976). Child-mother transmission of rotavirus (Letter). Lancet, 1, 96. 